\title{
Student Primary Teachers' Knowledge and Attitudes Towards Biotechnology-Are They Prepared to Teach Biotechnological Literacy?
}

\author{
Marina Casanoves de la $\mathrm{Hoz}^{1}$ (D) Anna Solé-Llussà ${ }^{(\mathbb{D})} \cdot$ Juan Haro $^{3}$ (D) Niklas Gericke $^{4}$ (D) Cristina Valls $^{5}$ (D)
}

Accepted: 6 October 2021 / Published online: 12 November 2021

(c) The Author(s) 2021

\begin{abstract}
The speed of development of biotechnology within agriculture, industry, and medicine has changed our lives, and we need a biotechnological literacy to understand it. This implies that teachers in primary schools need to be biotechnologically literate in order to educate future generations. The aim of this study was to investigate Swedish pre-service primary school teachers' knowledge of and attitudes towards biotechnology and contextualize the results by comparing them with a corresponding group of Spanish teachers. Data was collected using the established questionnaire instrument Biotech XXI and analyzed statistically. The findings demonstrate that Swedish pre-service primary school teachers have knowledge gaps relating to the basic genetic concepts that underpin biotechnology, although they are aware of biotechnological applications. Their attitudes are quite positive towards biotechnological applications in health, but less so to buying and using genetically modified products. Higher levels of knowledge were correlated with more positive attitudes, indicating an attitudinal basis for expanding the knowledge of and teaching practices for biotechnology among primary teachers. The level of knowledge and attitudes in the Swedish sample were similar to those of the Spanish teachers, suggesting a similar situation may be prevalent in many countries. The results indicate a need to reconsider the science curricula within pre-service primary school teacher training programs in order to better prepare primary teachers for teaching biotechnological literacy.
\end{abstract}

Keywords Attitudes towards biotechnology · Biotechnological literacy · Genetic education · Pre-service teachers' understanding $\cdot$ Primary education

Cristina Valls

cristina.valls@urv.cat

1 Faculty of Educational Sciences and Psychology, Department of Biochemistry and Biotechnology, Universitat Rovira i Virgili, Carretera de Valls S/N, Tarragona, Catalonia 43007, Spain

2 Faculty of Educational Science, Psychology and Social Work, Department of Specific Didactics, Universitat de Lleida, Lleida Av. de L'Estudi General, 4., Lleida, Catalonia 25001, Spain

3 Faculty of Educational Sciences and Psychology, Department of Psychology, Universitat Rovira i Virgili, Carretera de Valls S/N, Tarragona, Catalonia 43007, Spain

4 Department of Environmental and Life Sciences, Karlstad University, Universitetsgatan 2, Karlstad 65188, Sweden

5 Faculty of Educational Sciences and Psychology, Department of Biochemistry and Biotechnology, ARGET Research Group, Universitat Rovira i Virgili, Carretera de Valls S/N, Tarragona, Catalonia 43007, Spain

\section{Introduction}

During the twenty-first century, biotechnology is one of the science disciplines that has undergone the most rapid development, with significant implications for our society (Usak et al., 2009). Biotechnological applications raise ethical, social, and philosophical questions (Salvadó et al., 2013), and for most biotechnological applications, it is the public that judges their desirability and determines their success (Costa-Font $\&$ Mossialos, 2006). Therefore, it is important that primary education fosters biotechnological literacy early in children's schooling (Chabalengula et al., 2011); such literacy often contains knowledge and attitudinal dimensions (Bromme \& Goldman, 2014; Carver et al., 2017). In response to the biotechnological revolution, many curricula around the world now include biotechnology (Klop \& Severiens, 2007). However, this poses educational challenges to teachers, especially primary teachers, who often have limited biotechnological knowledge (Chabalengula et al., 2011). As primary school 
teachers have a large influence on the development of future generations' biotechnological literacy, it is important that we understand their knowledge and attitudes towards biotechnology, so that we can identify any need to revise and develop the biology curricula and guidance for the teachers.

\section{Background}

\section{The Importance of Biotechnological Literacy}

In order to involve society in the decision-making process about scientific policies, we need well-informed citizens who are able to make insightful decisions based on scientific conclusions. In this context, science education worldwide promotes, as an important goal of science teaching, scientific and technological literacy (Bybee et al., 2009; Roberts, 2007; Zoller, 2012).

The need for scientific literacy has been highlighted as important in the specific field of biotechnology (Salvadó et al., 2013; González et al. 2013; Carver et al., 2017). Biotechnology can be defined as the fastest growing industry in the production of commercial applications and products throughout the world (Straathof et al., 2019). Biotechnological literacy as a subset of scientific literacy is therefore important to enable people to consider and critically evaluate associated issues, to make informed decisions, and to develop opinions based on knowledge. Biotechnology is underpinned by scientific knowledge of the field of genetics (Bahri et al., 2014). Without a basic knowledge of genetics, it is difficult to evaluate biotechnological applications (Gericke \& Smith, 2014).

Over the last few decades, interest in biotechnological literacy has increased among science education researchers (Kidman, 2009; Klop \& Severiens, 2007; Sorgo \& Ambrozic-Dolinsek, 2009). These studies have assessed teachers' and students' perceptions and understanding of different aspects of biotechnology, including knowledge, fears, beliefs, and ethics related to the use of these new technologies. Some studies have highlighted the importance of introducing biotechnological knowledge into teacher training curricula in order to improve pre-service primary school teachers' self-efficacy in teaching about biotechnology (Delamarter, 2015; García-Carmona \& Cruz-Guzmán, 2016).

It has been shown that pre-existing attitudes and beliefs influence the way teachers understand what they learn during their training, and how they implement the content in their daily practice at school (Cebesoy \& Öztekin, 2017; Jiménez-Salas et al., 2017; Lee \& Ginsburg, 2007). Research also indicates that what teachers consider to be correct and important also influences the way they teach (Buehl \& Beck, 2015). In the case of biotechnology, this has been illustrated within higher education (Solli et al., 2014). Teachers with more positive attitudes towards science include science topics more often in the classroom and use active learning methodologies (Haney et al., 2002; Orhan \& Sahin, 2018). In order to enable all teachers to promote biotechnological literacy in primary education, we therefore first need to know pre-service primary school teachers' existing knowledge and attitudes.

\section{International Studies on Knowledge and Attitudes Towards Biotechnology}

In the first decade of the twenty-first century, there was a great interest in, and recognition of the importance of, exploring public knowledge of and attitudes towards the rise in biotechnological applications in society (e.g., Barnett et al., 2007; Condit, 2010; Gaskell et al., 2010). However, in the second decade, only a few studies have been published on this topic, yet the evolution of biotechnology and its impact in society have increased, as, for example, with the development of the gene scissors Crispr/Cas9 (Doudna \& Charpentier, 2014). This has led to a call to revisit the issue and see whether knowledge and attitudes towards biotechnology have changed as a consequence of these new applications.

Previous large, generalizable studies on knowledge and attitudes towards biotechnology have been conducted at a public level rather than in school contexts. The best baseline for comparisons is provided by the Eurobarometer surveys, conducted within many countries in Europe, including Sweden and Spain. However, the most recent survey on knowledge and attitudes towards biotechnology was published in 2010 (European Commission, 2010). According to European Commission (2010), about one in five adults in Europe is qualified as well-informed about biotechnology.

An important aspect of previous studies is that a difference in public attitudes and knowledge was found between northern and southern European countries. For example, in the Eurobarometer 2010 study, Sweden was ranked third among the 15 participating European countries, while Spain was ranked 12th. The Eurobarometer 2010 study also compared trends in optimism towards biotechnology and genetic engineering between the countries: $74 \%$ of Spanish citizens were optimistic about using these technologies, compared with $63 \%$ of Swedish citizens. In line with those finding, Magnusson and Hursti (2002) found that most Swedish consumers had moral and ethical doubts about eating GM foods, which were not outweighed by perceived attributes like better taste or lower price. However, less tangible benefits such as being better for the environment or healthier seemed to increase their willingness to purchase GM foods.

To conclude, as can be seen in the European Commission (2010) data, there were large differences between European countries in attitudes towards genetically modified (GM) food. The 
most positive attitudes to producing and consuming GM food were found in the Czech Republic, Slovakia, Portugal, and Spain, while Sweden, Italy, Austria, and Germany were among the most negative. It is clear from this that country-specific results should be contextualized within a European-wide context, and countries should be compared using the same instruments. To contribute to such comparison, in the study presented here, we investigated Swedish pre-service primary school teachers' knowledge and attitudes towards biotechnology and compared the results with previously obtained results from Spain using the same instrument and a comparable sample of pre-service primary school teachers. The participants (Spanish and Swedish) are seen as representatives of northern and southern European countries, respectively, that reportedly differ substantially in attitudes and knowledge regarding biotechnological issues (European Commission, 2010). Comparison of attitudes and knowledge of participants in these contrasting educational and cultural settings was expected to provide more general insights into student primary teachers' readiness to teach biotechnological literacy.

\section{Teachers' Attitudes and Knowledge Towards Biotechnology}

Teachers can play a central role in promoting biotechnological literacy. Biotechnological education and literacy are included in the biology curricula of most countries (Klop \& Severiens, 2007), including Sweden (Education, 2011) and Spain (Real Decreto, 1105/2014). Genetics is commonly taught in secondary school, but applied sciences such as biotechnology, in which pupils meet science as part of their everyday lives, should be taught in primary education (Laugksch, 2000), as many values and beliefs are formed at this level of schooling.

Most studies to date have only investigated public understanding of biotechnology, e.g., Carver et al. (2017). Only a few studies appear to have investigated primary school teachers' attitudes and knowledge in biotechnology, in five different countries: Slovakia (Prokop et al., 2007), Lithuania (Lamanauskas \& Makarskaite-Petkeviciene, 2008), Slovenia and Turkey (Šorgo et al., 2011), Turkey (Darçin, 2011), USA (Chabalengula et al., 2011), and Spain (Casanoves et al., 2015). The study from Slovakia found that student teachers held numerous misunderstandings about biotechnologies, but with a significant correlation between positive attitudes and increased level of knowledge (Prokop et al., 2007). The Lithuanian study of Lamanauskas and Makarskaite-Petkeviciene (2008) similarly revealed that knowledge about biotechnology among student teachers was poor and that no significant differences between student teachers studying biology and those studying other subjects were found. Šorgo et al. (2011) found in a study of Slovenian and Turkish teachers that knowledge of genetics and biotechnology influenced their attitudes towards genetic modification in a slightly positive direction.
In another study of Turkish teachers, no correlations could be seen between knowledge level and attitudes (Darçin, 2011). A study from the USA showed that most pre-service primary school teachers had positive attitudes to the use of biotechnological applications and the genetic modification of food and plants. However, the majority of those pre-service primary school teachers disapproved of the genetic modification of humans and animals (Chabalengula et al., 2011). A Spanish study (Casanoves et al., 2015) showed that pre-service primary school teachers were aware of biotechnological applications, but knew less about the actual technological procedures. The Spanish pre-service primary school teachers' attitudes were positive towards the use of biotechnology for medical purposes and were highly interested in the topic.

Overall, most research about attitudes to and understanding of biotechnology is about 10 years old, and data from many specific contexts, such as Swedish pre-service primary school teachers, is missing. This exposes an important research gap because pre-service primary school teachers will be highly influential in shaping future generations' knowledge and attitudes towards biotechnology. The aim of this study was therefore to explore this issue by investigating pre-service primary school teacher students' knowledge of and attitudes towards biotechnology.

\section{Aim and Research Questions}

The study analyzes Swedish pre-service primary school teachers' views of two aspects of biotechnology to address the following research questions: (i) the level of their biotechnological knowledge, (ii) their attitudes towards biotechnology, (iii) and the correlation between knowledge and attitudes. (iv) A comparison was then made between the data from the present Swedish sample with data collected previously from Spanish pre-service primary school teachers (Casanoves et al., 2015), in order to see whether there were any differences in knowledge and/or attitudes between a northern European country and a southern European country.

\section{Methods}

\section{Participants and Data Collection}

The study was conducted with a sample of 155 student primary teachers $(26.61 \pm 7.21$ years old; $86 \%$ female and $14 \%$ male) from a large teacher training university in the middle of Sweden. The students were taking one of three different teacher training programs: "preschool education" (including first years at primary education), "primary education (grades 1 to 3)," and "primary education (grades 4 to 6)." Within those programs, the students' took a general science course during one semester, which had only limited content 
related to biotechnology. The students had also had a general science course in their previous secondary schooling, which covered genetics and biotechnology to some extent.

A paper questionnaire was distributed to the students in class by the first author. Hence, all the participants were given the same instructions under controlled conditions.

The Spanish data came from a previous sample of 407 student teachers from two educational universities in two major cities in the province of Catalonia. All participating students were taking a program called "preschool and primary education," and the questionnaire had been distributed to them in the same way (Casanoves et al., 2015).

Both studies followed the ethical guidelines of the respective countries; participation was voluntary, and the responses were anonymized.

\section{Instrument Design}

The instrument used was the Biotech XXI questionnaire. This had been developed in a previous study and validated with a sample of Spanish pre-service primary school teachers (Casanoves et al., 2015). The reliability and validity of the Swedish data are accounted for here. The instrument is based on a biotechnology framework, including topics such as genetics, molecular biology, and genetically modified organisms (GMO). It contains items taken from previously published and validated surveys (Chabalengula et al., 2011; European Commission, 2010; Klop \& Severiens, 2007; Prokop et al., 2007), as well as novel items constructed to implement the framework. The questionnaire consisted of three distinct sections. The first section was designed to obtain socio-demographic information about the respondents. The second section comprised 21 true/false/don't know items that assessed the respondents' knowledge of biotechnology, including genetic knowledge and biotechnological applications; see Table 1 . The third section was a 4-point Likert-scale questionnaire with 45 items, for which respondents rated their opinions on statements about biotechnological applications as 1 (strongly disagree), 2 (disagree), 3 (agree), and 4 (strongly agree), see Table 2 . For a full and detailed description of the instrument, see Casanoves et al. (2015).

Table 1 Knowledge items with the most frequent correct responses among Swedish teachers. In the column "correct answer," $\mathrm{T}$ (true) and $\mathrm{F}$ (false)

\begin{tabular}{|c|c|c|c|c|c|}
\hline Number & Item & Correct answer & $\begin{array}{l}\text { Responded } \\
\text { correctly } \\
(\%)\end{array}$ & $\begin{array}{l}\text { Responded } \\
\text { incorrectly } \\
(\%)\end{array}$ & $\begin{array}{l}\text { Don't } \\
\text { know } \\
(\%)\end{array}$ \\
\hline 1 & AIDS is a genetic disease & False & 83 & 14 & 4 \\
\hline 2 & $\begin{array}{l}\text { Bacteria are used in the elaboration of daily products (cheese, vinegar, vitamin } \\
\text { C) }\end{array}$ & True & 80 & 6 & 14 \\
\hline 3 & Only when we eat GM food we eat genes & False & 78 & 7 & 15 \\
\hline 4 & In our body, there are more bacteria than people in the world & True & 77 & 8 & 14 \\
\hline 5 & A good hygiene helps to prevent genetic diseases & False & 75 & 15 & 9 \\
\hline 6 & Children resemble their parents because they share the red blood cells & False & 72 & 8 & 21 \\
\hline 7 & $\begin{array}{l}\text { It is possible to change the genetic characteristics of a plant to make it more } \\
\text { resistant to a given plague }\end{array}$ & True & 65 & 9 & 26 \\
\hline 8 & Mutations are only possible by genetic manipulation in the laboratory & False & 65 & 16 & 19 \\
\hline 9 & $\begin{array}{l}\text { A high production of vitamins by a fruit is only possible by genetic manipulation } \\
\text { of that fruit }\end{array}$ & False & 63 & 11 & 26 \\
\hline 10 & $\begin{array}{l}\text { Through genetic modification, foods with higher nutritional values can be } \\
\text { achieved }\end{array}$ & True & 50 & 13 & 37 \\
\hline 11 & Microorganisms are used to purify sewage & True & 48 & 11 & 41 \\
\hline 12 & A yogurt is a biotechnological product & True & 41 & 17 & 42 \\
\hline 13 & Insulin is obtained by the use of genetically modified (GM) bacteria & True & 38 & 16 & 46 \\
\hline 14 & $\begin{array}{l}\text { Genetic material exchange between different species is only possible by } \\
\text { manipulation in the laboratory }\end{array}$ & False & 35 & 32 & 32 \\
\hline 15 & The most powerful toxic substances are naturally occurring & True & 34 & 30 & 36 \\
\hline 16 & GMO have a high number of toxic substances & False & 33 & 19 & 48 \\
\hline 17 & Chemically, the genetic material (DNA) is identical in all the organisms & True & 32 & 41 & 28 \\
\hline 18 & $\begin{array}{l}\text { In the kidney cells genome, you can also find the information about the color } \\
\text { of your hair }\end{array}$ & True & 27 & 26 & 47 \\
\hline 19 & Genetically modified organisms (GMO) are larger than normal & False & 21 & 26 & 53 \\
\hline 20 & Crocodiles have the same genetic material as ostriches & True & 17 & 34 & 50 \\
\hline 21 & A GMO is always a transgenic & False & 8 & 22 & 70 \\
\hline
\end{tabular}


In order to administer the questionnaire to the Swedish student teachers, the questionnaire was translated into Swedish based on a developed English standard version of the original (Casanoves et al., 2015). A second independent back translation was then made into English to secure the validity of the translation. Some changes were made based on the back translation, and the final items piloted with a group of 15 Swedish pre-service primary school teachers to make sure the questionnaire were understood as intended.

\section{Statistical Analysis}

Analyses were performed using SPSS Statistics 20. First, we checked the reliability of the second (knowledge items) and third (attitudes) sections of the questionnaire by calculating Cronbach's $\alpha$ (CA). Second, we conducted an exploratory factor analysis (principal component analysis with varimax rotation) to find the factorial structure of participants' attitudes towards biotechnology. We used a Horn's parallel analysis and Screen test to select the optimal number of factors. The factorial scores of each participant were interpreted from their attitudes towards biotechnology, from 1 (strongly disagree) to 4 (strongly agree). These scores were later entered into a $K$-means cluster analysis to group participants with similar attitudes. We also calculated some correlation coefficients: Pearson's correlation coefficient ( $r$; between quantitative variables), a biserial-point coefficient ( $r p b$; between nominal and quantitative variables), a biserial coefficient ( $r b$; between ordinal and quantitative variables), and a rankbiserial coefficient ( $r r b$; between ordinal variables).

Finally, the knowledge and factorial scores from the Swedish and the Spanish samples were compared using independent sample $t$-tests. In addition, Pearson's chisquare tests were performed to compare the percentage of correct answers in the knowledge section between the two samples ("don't know" answers were considered to be incorrect answers). Analyses of the reliability and validity of the Spanish data can be found in Casanoves et al. (2015).

\section{Results}

\section{Knowledge of Biotechnology}

The biotechnological knowledge section of the questionnaire comprised 21 questions. The CA value for this section was 0.66, which is acceptable according to Nunnally (1978). Table 1 shows the 21 items ordered from the highest to the lowest percentage of correct answers. The first 10 items were answered correctly by more than $50 \%$ of the Swedish student teachers, while the last 11 items represent questions that were answered incorrectly, or marked as "don't know," by more than $50 \%$ of students.
As shown in Table 1, we found that the Swedish preservice primary school teachers lacked knowledge about many basic concepts of genetics and about some aspects of biotechnology related to GMO. For instance, $68 \%$ of the students answered incorrectly, or did not know, that DNA is chemically identical in all organisms. Only $21 \%$ knew that GMOs are not necessarily larger than other organisms, and many were unsure about whether GMO contained toxic substances. However, the respondents had a fairly good understanding of some of the biotechnological applications. For example, $80 \%$ of the students were aware that bacteria are used in the manufacture of cheese and vinegar, among other daily products, and $65 \%$ of students knew that it is possible to change genetic characteristics in order to increase an organism's resistance to disease, increase nutritional values, or increase productivity.

\section{Attitudes Towards Biotechnology}

This section consisted of 45 items; the reliability score (Cronbach's $\alpha$ ) was 0.81 , indicating high reliability. In general, the Swedish student teachers had a relatively neutral attitude towards biotechnology, with an average score for each of the 45 items of $2.61( \pm 0.89)$, just above the overall mean of 2.5.

Each participant's attitude towards biotechnology was interpreted using a factorial score based on the mean value for each item. The suitability of the respondents' data for the analysis was supported by two measures: the Kaiser-Meyer-Olkin test, with a value of 0.74 , and the Barlett's test, which was statistically significant $(p<0.001)$. We included the responses to the 45 attitude items in an exploratory factor analysis, resulting in four factors that explained $37.7 \%$ of the total variance (see Table 2 ). Three items were deleted because their factor loadings were lower than 0.3 . The four explanatory factors that were examined further were named: general opinion of GMO applications, personal feelings towards GMO, biotechnology and health, and interest in biotechnology.

\section{General Opinion of GMO Applications}

This factor had an average score of $2.58( \pm 0.16)$; see Table 2. It included 14 items (Cronbach's $\alpha=0.586$ ) that expressed perceptions and opinions about the use of GMO at individual and societal levels. However, the majority of the students did not have a clear standpoint for most of the items in this factor. For example, $57 \%$ of the students did not think that consumption of GM foods was dangerous, but $67 \%$ of them said that genetic manipulation should be more strictly regulated. Hence, the student teachers' opinions were diverse and inconsistent within this factor, which could explain the relatively low CA value. 
Table 2 Factor structure and loading of the 42 items related to attitudes towards biotechnology

Attitude (\%)

Number Item

Average SD Loading Strongly negative Negative Positive Strongly positive rating rating item factor

Factor 1: general opinion of GMO applications dangerous. ${ }^{*}$ d

$$
3
$$

3 Genetic manipulation will drive to the extinction of a large number of species.*$$
\text { my country. }
$$

$5 \quad$ The genetical modification of fruits and 2.87

plants to be fresh for a longer time. ${ }^{\mathrm{C}}$

\section{6}

11 Genetic manipulation should be more

12 The application of biotechnology will 2.43

make the future more dangerous.
13 If I get a dish in a restaurant made out of 2.47 transgenic food, I would not eat it. ${ }^{{ }_{c}}$

14 The genetic modification of a sheep to produce medicines. $^{\text {a }}$

Factor 2: personal feelings towards GMO

1 If genetically modified food was cheaper, I would buy it

2 The alteration of the genes of a fruit to 1.84 make it more tasty. ${ }^{\mathrm{c}}$

3 The labeling of the transgenic products $\quad 1.85$ is clear enough

$4 \quad$ I would buy GM food

If genetically modified foo I would eat them more often. ${ }^{c}$

6 I would feed my children with food $\quad 1.95$ produced with GM bacteria

$7 \quad$ The genetic modification of a bacteria to 2.37 produce food

8

Society should decide what is right or $\quad 2.32$ wrong in science

9

GM foods can help alleviate world hunger. $^{\mathrm{c}}$

10 Biotechnology does not play any role in 2.9 environmental protection.

11 Biotechnology is used to produce chemicals in a less polluted way 
Table 2 (continued)

\begin{tabular}{|c|c|c|c|c|c|c|c|c|}
\hline \multirow[b]{2}{*}{ Number } & \multirow[b]{2}{*}{ Item } & \multirow[b]{2}{*}{$\begin{array}{l}\text { Average } \\
\text { rating }\end{array}$} & \multirow[b]{2}{*}{$\begin{array}{l}\mathrm{SD} \\
\text { rating }\end{array}$} & \multirow[b]{2}{*}{$\begin{array}{l}\text { Loading } \\
\text { item factor }\end{array}$} & \multirow[b]{2}{*}{ Strongly negative } & \multicolumn{2}{|c|}{ Attitude (\%) } & \multirow[b]{2}{*}{ Strongly positive } \\
\hline & & & & & & Negative & Positive & \\
\hline \multicolumn{9}{|c|}{ Factor 3: biotechnology and health } \\
\hline 1 & Biotechnology makes our lives easier. $^{c}$ & 2.98 & 0.62 & 0.63 & 1.94 & 14.19 & 67.74 & 16.13 \\
\hline 2 & $\begin{array}{l}\text { I agree with the genetic investigation in } \\
\text { medicine }\end{array}$ & 2.95 & 0.77 & 0.61 & 3.87 & 20.65 & 52.26 & 23.23 \\
\hline 3 & $\begin{array}{l}\text { I would support the use of GMO for } \\
\text { non-food purposes }\end{array}$ & 2.39 & 0.79 & 0.61 & 14.19 & 36.77 & 44.52 & 4.52 \\
\hline 4 & Biotechnology can improve our life style & 2.98 & 0.74 & 0.59 & 3.87 & 16.77 & 56.77 & 22.58 \\
\hline 5 & $\begin{array}{l}\text { The use of GMO for medical therapy } \\
\text { and the study of diseases. }{ }^{c}\end{array}$ & 2.79 & 0.65 & 0.59 & 2.58 & 26.45 & 60.65 & 10.32 \\
\hline 6 & $\begin{array}{l}\text { Biotechnology is evil for nowadays } \\
\text { society. }\end{array}$ & 3.06 & 0.64 & 0.56 & 1.94 & 11.61 & 65.16 & 21.29 \\
\hline 7 & $\begin{array}{l}\text { The use of GMO to fight against } \\
\text { diseases }\end{array}$ & 2.61 & 0.72 & 0.49 & 5.81 & 34.84 & 51.61 & 7.74 \\
\hline 8 & The law about GMO is strict enough & 2.37 & 0.68 & 0.47 & 7.74 & 50.32 & 38.71 & 3.23 \\
\hline 9 & $\begin{array}{l}\text { I agree with the genetic transforma- } \\
\text { tion in embryos to cure hereditary } \\
\text { diseases. }^{\text {a }}\end{array}$ & 2.65 & 0.90 & 0.44 & 12.90 & 25.16 & 45.81 & 16.13 \\
\hline 10 & $\begin{array}{l}\text { A scientific discovery is not "good" or } \\
\text { "bad," is how we use what matters. }\end{array}$ & 3.43 & 0.70 & 0.42 & 1.29 & 8.39 & 36.77 & 53.55 \\
\hline 11 & Science makes our lives easier. ${ }^{\mathrm{b}}$ & 3.19 & 0.79 & 0.40 & 3.23 & 13.55 & 43.87 & 39.35 \\
\hline 12 & $\begin{array}{l}\text { The clonation as a tool to save endan- } \\
\text { gered species. }{ }^{\text {d }}\end{array}$ & 2.59 & 0.84 & 0.31 & 10.32 & 32.90 & 44.52 & 12.26 \\
\hline \multicolumn{9}{|c|}{ Factor 4: interest } \\
\hline 1 & $\begin{array}{l}\text { I would like to know more about GM } \\
\text { food. }^{\mathrm{d}}\end{array}$ & 3.10 & 0.85 & 0.84 & 5.81 & 14.19 & 44.52 & 35.48 \\
\hline 2 & $\begin{array}{l}\text { I would like to have more information } \\
\text { about GM food }\end{array}$ & 3.15 & 0.91 & 0.80 & 7.10 & 12.90 & 37.42 & 42.58 \\
\hline 3 & $\begin{array}{l}\text { I would like to increase my knowledge } \\
\text { about GMO }\end{array}$ & 3.08 & 0.86 & 0.74 & 5.16 & 17.42 & 41.29 & 36.13 \\
\hline 4 & $\begin{array}{l}\text { I would like to be aware of scientific } \\
\text { advances }\end{array}$ & 3.21 & 0.77 & 0.72 & 3.87 & 9.68 & 47.74 & 38.71 \\
\hline 5 & Biotechnology is boring. ${ }^{*}$ & 2.57 & 0.89 & 0.45 & 11.61 & 34.84 & 38.06 & 15.48 \\
\hline
\end{tabular}

The Table shows respondents' attitudes (positive or negative) towards biotechnological issues. Responses to items presented as negative sentences were reversed in order to obtain a visually meaningful graphical representation of a positive or negative attitude to the different aspects of biotechnology included in the survey. Items with reversed answers are identified with an asterisk. Items from published instruments are identified by superscript letters:

${ }^{\text {a }}$ Chabalengula et al. (2011)

${ }^{\mathrm{b}}$ European Commission (2010)

${ }^{\mathrm{c}} \mathrm{Klop}$ (2008)

${ }^{\mathrm{d}}$ Lamanauskas and Makarskaite-Petkeviciene (2008)

\section{Personal Feelings Towards GMO}

The second factor had a mean value of $2.28( \pm 0.38)$; see Table 2. It consisted of 11 items mainly representing personal feelings and consumer tendencies towards GMO products (Cronbach's $\alpha=0.768$ ). In general, the student teachers had negative attitudes towards GMO-produced food and would avoid the consumption of GM food, even when the benefit to the consumer in terms of tastier or cheaper food was considered (items 1, 2, 5, and 7 of factor 2). However, if the genetic modification of food production was focused on healthier products, there was a tendency towards being more likely to buy it.

\section{Biotechnology and Health}

The third factor had a mean value of $2.83( \pm 0.32)$ and included 12 items (Cronbach's $\alpha=0.775$ ); see Table 2. The 
main theme of this factor was biotechnological innovations in health care applications. The students had more positive attitudes to using new biotechnological advances for health purposes. For example, $71 \%$ of the students agreed with the use of GMO for medical therapy and the study of diseases, and three in four respondents approved of the use of genetic investigations in the development of medicine.

\section{Interest in Biotechnology}

The fourth factor had a mean value of $3.02( \pm 0.26)$ and comprised 5 items related to interest in biotechnology (Cronbach's $\alpha=0.792$ ); see Table 2. In general, the students were very interested in knowing more about biotechnological topics. For example, $77 \%$ of the students declared that they would like to improve their knowledge about GMO.

\section{Clustering of Attitudes Towards Biotechnology}

We then analyzed whether clusters of individuals could be identified among the sample of Swedish students, by performing a $K$-means cluster analysis. The result was two interpretable clusters (see Fig. 1), which differed significantly regarding factor 2 , personal feelings towards GMO $(t(155)=2.58, p<0.01)$, and factor 3 , biotechnology and health $(t(155)=13.59, p<0.001)$. However, the clusters did not differ significantly for factor 1 (general opinion of GMO applications) or factor 4 (interest in biotechnology) (all ps >0.05). We called these clusters "the skeptical" and "the confident."

\section{The Skeptical}

Cluster 1 included 48 students. These students were more negative than the others about the use of biotechnology in medical applications to improve living standards and the consumption of GMO products. They showed a lower mean score in attitude towards biotechnological applications in healthcare (factor 3), suggesting that they were less inclined to support genetic investigations into medicinal development, and the use of GMO in medical therapy (item $2(2.95 \pm 0.77)$ and item $5(2.79 \pm 0.65)$ from factor 3 ). They did not want to eat GM food, or members of their family to eat it, even if it would be cheaper or tastier (item $1(1.92 \pm 0.79)$, item $2(1.84 \pm 0.74)$, item $4(2.14 \pm 0.81)$, and item $6(1.95 \pm 0.74)$ from factor 2). Furthermore, they did not like the idea of using GM bacteria to produce food, and they felt that the labeling of transgenic products is not clear enough (item $3(1.84 \pm 0.62)$ and item $7(2.37 \pm 0.78)$ from factor 2).

\section{The Confident}

Cluster 2 included 107 students. These students were more positive towards GMO products generally. They were more positive about eating GM food, and offering GM food to their families (item $1(1.92 \pm 0.79)$, item $4(2.14 \pm 0.81)$, item $5(2.50 \pm 0.90)$, and item $6(1.95 \pm 0.74)$ from factor 2$)$. They agreed that medical applications of biotechnology could improve living standards, and they trusted biotechnological applications for medical therapy, the study of diseases,

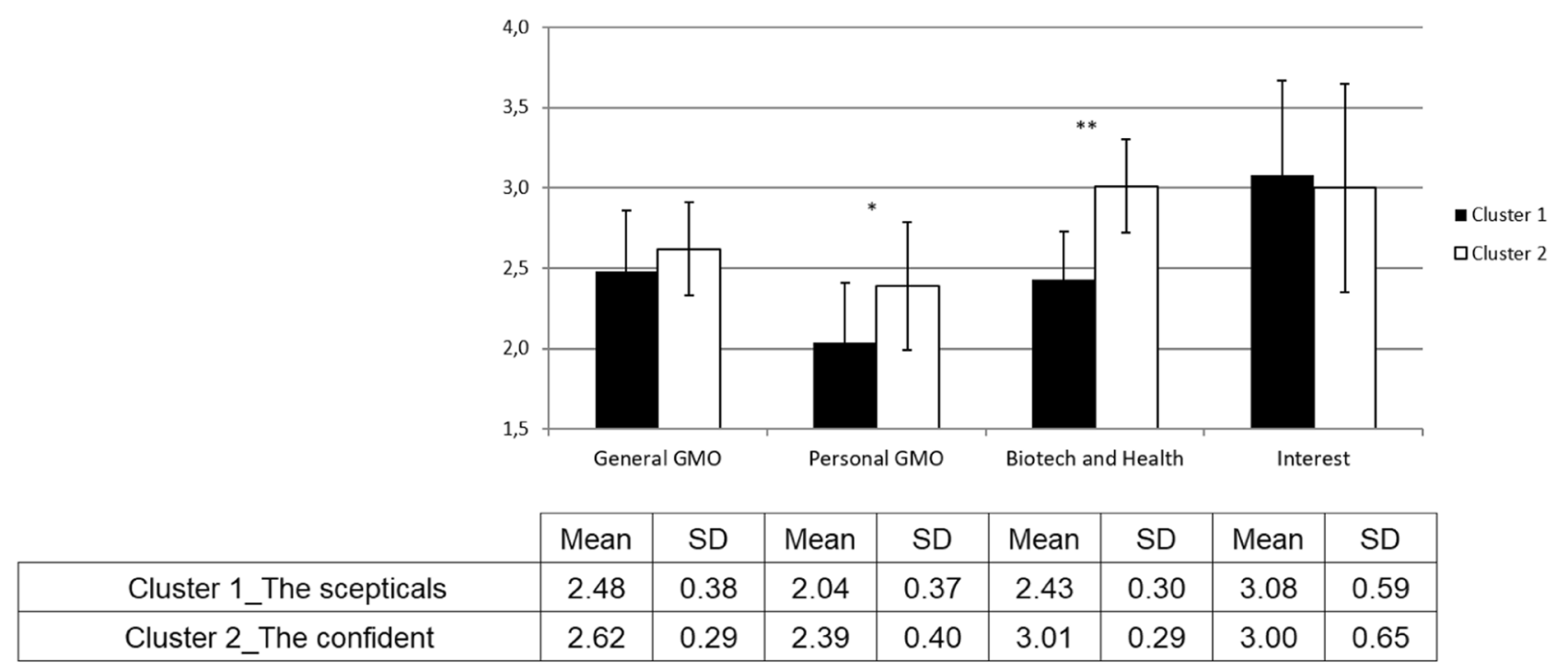

Fig. 1 A graphical representation of the $K$-means cluster analysis of attitudes towards biotechnology. General GMO corresponds to factor 1, personal GMO corresponds to factor 2, STS corresponds to factor 3 (biotechnology and health), and interest corresponds to factor
4 of the exploratory factor analysis. **Significance of $p<0.01$ and ${ }^{*} p<0.05$ using the $t$-test statistical analysis between factors of each cluster. The attitude scale ranged from 1 (strongly negative) to 4 (strongly positive) 
and genetic transformation in embryos to cure hereditary diseases (item $9(2.65 \pm 0.90)$ from factor 3$)$.

\section{Correlations Between Knowledge and Attitudes}

Correlation coefficients were calculated to examine to what extent the socio-demographic data, knowledge scores, and attitude scores of the student teachers were related (Table 3). Significant correlations were observed between knowledge and attitude scores. Pre-service primary school teachers who scored better marks in the knowledge section had more positive attitudes towards biotechnological applications related to health, and they showed more interest in increasing their knowledge of biotechnology-related topics. This was illustrated by the correlations found between knowledge and factor 3 (biotechnology and health) and factor 4 (Interest in Biotechnology); see Table 3.

\section{Comparison Between Swedish and Spanish Samples}

Once analyses of the Swedish data were complete, we compared the results statistically with data from a similar Spanish sample, see the "Methods" section and Casanoves et al. (2015).

\section{Knowledge of Biotechnology}

We carried out an independent $t$-test in order to compare the knowledge sections from the Swedish and Spanish questionnaires. The results showed no differences between the samples regarding total knowledge scores, $t(560)=1.05$, $p>0.05$, suggesting that Swedish and Spanish students have similar levels of knowledge relating to genetics and biotechnological applications.

\section{Attitudes Towards Biotechnology}

For the Spanish sample, the average value relating to attitudes was $2.69( \pm 0.89)$. Four factors were identified in the Spanish respondents' attitudes to different aspects of biotechnology; see the "Background" section and Casanoves et al. (2015) for an outlined description. These were GMO, biotech and health, science-technology-society, and interest in biotechnology. The factor analysis for the Swedish data also divided the attitude items into four factors: general opinion of GMO applications, personal feelings towards GMO, biotechnology and health, and interest in biotechnology.

A comparison between the Swedish and Spanish students' perceptions relating to attitudes towards biotechnology was made by calculating Pearson's correlation coefficients between the factor loadings of the 45 items in each questionnaire. The results revealed a correlation between the factor called "GMO" (factor 1) in the Spanish sample and the factor called "personal feelings towards GMO" (factor 2) in the Swedish sample $(r=.56, p<.01)$. These factors had a similar basis relating to students' personal opinions about the implications and consequences of using new technologies related to GM products and their personal behaviors about consuming those products.

We also found a positive and significant correlation between the factor called "science-technology-society" (factor 3) in the Spanish sample and the factor called "general opinion of GMO applications" (factor 1) in the Swedish students $(r=.49, p<.01)$. These factors indicated a common concern about the applications of GMO in global and social contexts.

The factor called "biotechnology and health" (factor 2 for Spanish and factor 3 for Swedish student teachers) showed a positive and significant correlation between the countries $(r=.54, p<.01)$. It appeared that Spanish as well as Swedish student teachers grouped items related to new biotechnological applications in the field of healthcare in a similar way.

Finally, the factor called "interest in biotechnology" (factor 4 in both countries) included the same five items in both countries and showed a high correlation between the samples $(r=.81, p<.01)$.

The high correlations between these four factors from each country indicated a high factorial similarity between the data sets and, thus, allowed us to compare the factorial scores of the Spanish and Swedish students. Because the samples differed in a number of participants, we selected a random subset of 155 participants from the Spanish sample to conduct $t$-tests (Bruce, 2015) (Fig. 2). The results showed a significant difference between the factor called "science-technology-society" (factor 3) for the Spanish sample and the factor called "general opinion of GMO applications" (factor 1) for the Swedish sample $(t(308)=3.204, p<.01)$. This indicated that Spanish respondents (mean 2.71, SD 0.41 ) were in general slightly more positive in their attitudes
Table 3 Correlations between socio-demographic data, knowledge scores, and attitude scores

\begin{tabular}{|c|c|c|c|c|c|}
\hline Parents & Knowledge & General GMO & Personal GMO & $\begin{array}{l}\text { Biotech } \\
\text { health }\end{array}$ & $\begin{array}{l}\text { Interest in } \\
\text { biotechnology }\end{array}$ \\
\hline Knowledge & & .067 & .017 & $.262^{* *}$ & $.169^{*}$ \\
\hline General GMO & & & $.329^{* *}$ & $.336^{* *}$ & .017 \\
\hline Personal GMO & & & & $.427^{* *}$ & .134 \\
\hline Biotech health & & & & & $.244^{* *}$ \\
\hline
\end{tabular}

Reported statistical significance: ${ }^{*} p<0.05 ;{ }^{* *} p<0.01$ 


\section{Factors Comparison}

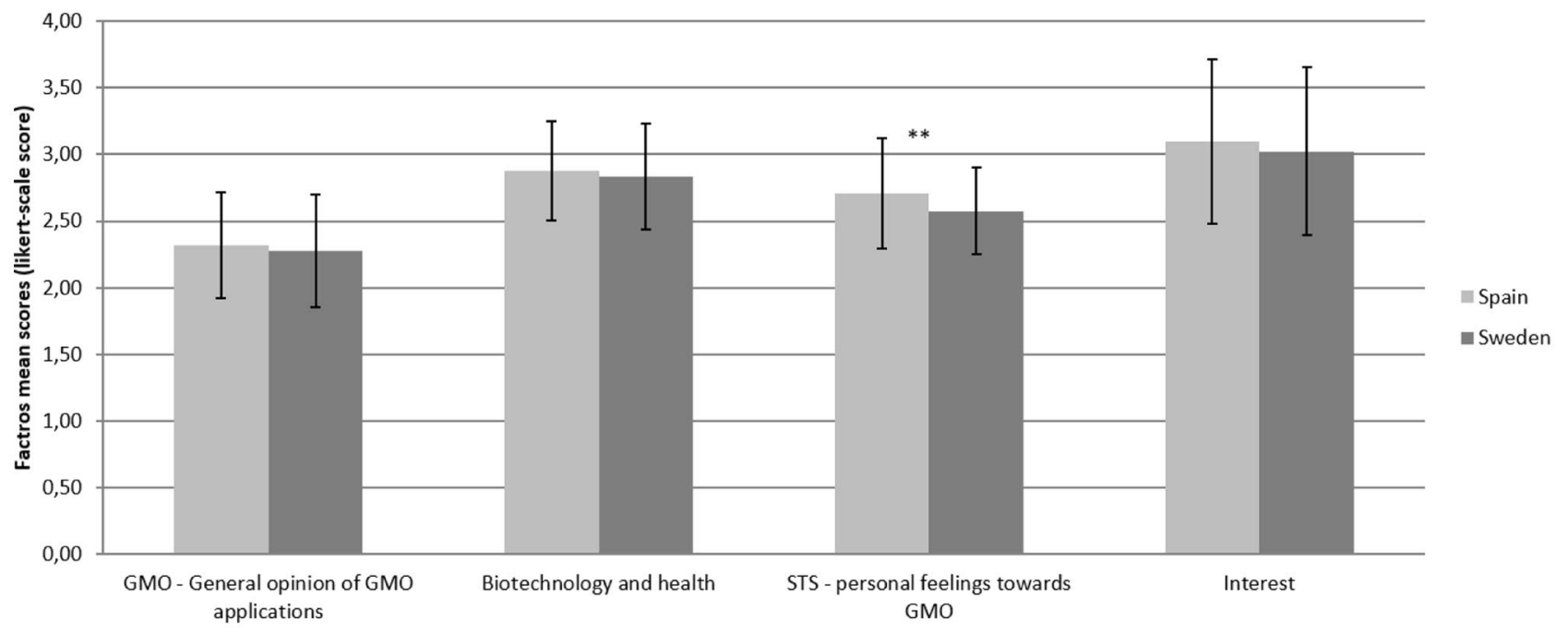

Fig. 2 A graphical representation of independent $t$-test for factor comparisons. Factor 1 Spain (GMO) with factor 1 Sweden (General GMO), factor 3 Spain (STS) with factor 2 Sweden (personal GMO), factor 2 Spain with factor 3 Sweden (biotechnology and health), and

to issues concerning applications of GMO than the Swedish pre-service primary school teachers (mean 2.58, SD 0.33).

No statistically significant differences were found between the factor "GMO" (factor 1) from the Spanish sample and the factor "personal feeling towards GMO" (factor 2) from the Swedish pre-service primary school teachers. Both populations showed a slightly negative attitude towards buying or consuming GMO (Sweden, mean 2.28, SD 0.42) (Spain, mean 2.32, SD 0.40). Furthermore, the student teachers displayed similar attitudes to the factor "biotechnology and health" (factor 2 for Spanish and factor 3 for Swedish) in both countries; our analysis did not find any significant differences between the average values of these two factors (Spanish mean 2.88, SD 0.37 and Swedish mean 2.83, SD 0.40). Hence, attitudes towards biotechnological applications in healthcare were generally positive in both countries. Finally, the factor "interest in biotechnology" (factor 4 in both countries) showed no significant differences between the two countries. Both Spanish (mean 3.10, SD 0.62) and Swedish respondents (mean 3.02, SD 0.63) expressed a high interest in biotechnological issues.

\section{Discussion}

This study analyzed Swedish primary education preservice primary school teachers' knowledge and attitudes towards biotechnology and then compared them with a similar dataset from Spain. The two countries were chosen to represent a northern European and southern European country, respectively. interest in biotechnology corresponding to factor 4 in both countries. $* *$ Significance of $p<0.01$. The attitude scale ranged from 1 (strongly negative) to 4 (strongly positive)

\section{Swedish Pre-service Primary School Teachers' Biotechnological Knowledge}

The knowledge test revealed that Swedish pre-service primary school teachers scored a high percentage of correct answers for questions related to understanding genetic disease and applications of biotechnology. Lower scores were obtained for questions related to basic concepts of genetics as well as questions related to GMO. The European Commission (2010) study revealed that Europeans in general did not score highly regarding knowledge of the basic concepts of genetics. In accordance with these earlier findings, the Swedish and Spanish, pre-service primary school teachers discussed here show a lack of knowledge about basic genetics that could negatively influence their ability to address biotechnological applications in their teaching. However, there were some exceptions to this trend. Most of the Swedish pre-service primary school teachers $(78 \%)$ in our study knew that both GM food and non-GM food contained genes, which was higher than in a study by Magnusson and Hursti (2002) carried out almost 20 years ago, which found that only $67 \%$ of Swedish consumers could answer a similar question. Hence, some positive trends were seen.

Both Swedish and Spanish pre-service primary school teachers achieved a higher percentage of correct answers on questions related to uses of biotechnology compared with studies of Slovakian (Prokop et al., 2007), Turkish (Usak et al., 2009), and Lithuanian (Lamanauskas \& MakarskaitePetkeviciene, 2008) student teachers. But in relation to 
questions concerning more basic genetics, such as DNA structure and cell management of genetic information, both Swedish and Spanish pre-service primary school teachers showed the same meagre knowledge level as found in other countries, such as Turkey, Slovakia, Slovenia, Lithuania, and Lebanon (Darçin \& Güven, 2008; Erdoğan et al., 2012; Lamanauskas \& Makarskaite-Petkeviciene, 2008; Sorgo \& Ambrozic-Dolinsek, 2009).

Because of a lack of understanding of basic genetic concepts, an understanding of more complex biotechnologies may be difficult for these pre-service primary school teachers. Our study indicates that the lack of knowledge identified some 10 years ago still seems to exist. It seems that biotechnological literacy has not yet been accomplished, and primary teachers will therefore presumably struggle to develop this literacy among future generations.

\section{Swedish Pre-service Primary School Teachers' Attitude Towards Biotechnology}

One of the aims of this study was to analyze the Swedish pre-service primary school teachers' attitudes towards biotechnology. They showed an average score for attitudes to biotechnology of $2.61( \pm 0.89)$, indicating a neutral attitude. The students could generally be defined as opponents to buying GM products, but supporters of biotechnology for medical purposes and highly interested in increasing their knowledge about biotechnological and scientific advances. The Swedish pre-service primary school teachers were not judging the "biotechnology" as such, but they did seem to judge its purpose and use. This could be indicative of an underlying utility-value system that is influencing a shift in attitudes towards GMO applications, based on what the technology is being used for. Hence, GMO is acceptable when it is being used to save human lives or prevent disease, but it is not acceptable for enjoyment or economic gain. In accordance with this idea, a previous study by Magnusson and Hursti (2002), of a population of Swedish consumers, showed similar results. Our Swedish pre-service primary school primary teachers had similar values for items included in factor 3 "personal feelings towards GMO," in which their attitudes about buying, consuming, or producing GM products were assessed. The attitudes of our Swedish student teachers therefore seem to be similar to attitudes of the population as a whole, and these attitudes do not seem to have changed much over the last 15 years.

However, these attitudes are not in line with scientific statements that describe GMO as being relatively unproblematic (Almomani et al., 2020; Brosig \& Bavorova, 2019; Carver et al., 2017) but are instead an expression of a value system relating to the purpose of the technology. This value system seemed to predominate in the skeptical group, which made up a third of the respondents. Because of the limited level of scientific understanding of related genetic concepts, it is likely that these attitudes and values will influence the way these students go on to teach about GMO and biotechnologies. Therefore, it is important to provide schools and teacher training with adequate teaching materials that cover the basic scientific facts and make clear the differences between knowledge, values, and ethics.

We also looked for any possible correlations between student knowledge level and attitudes towards biotechnology. Students with higher scores in the knowledge section of the questionnaire also expressed more positive attitudes towards biotechnology related to health applications and a higher interest in biotechnology. There is therefore some evidence that gaining knowledge can lead to more positive attitudes, as has also been found in studies from the UK (Costa-Font \& Mossialos, 2006), and Slovenia and Turkey (Šorgo et al., 2011), but in contrast to studies from the USA (Chabalengula et al., 2011) and Turkey (Darçin, 2011). This issue requires more research before generalizations can be made, but our study suggests that improving student teachers' knowledge of biotechnological issues could lead to more positive attitudes towards biotechnology.

\section{Comparison Between Swedish and Spanish Pre-service Primary School Teachers}

No significant differences between the Swedish and Spanish pre-service primary school teachers were found regarding knowledge. This suggests that Swedish and Spanish students have the same level of knowledge about biotechnology and do not support the differences found by European Commission (2010).

Four very similar factors were found in both studies, thus the Swedish and Spanish pre-service primary school teachers' perceived attitudes towards biotechnology were very similar. The level of positive attitudes was also similar. Significant differences were only found regarding the application of GMO within society, suggesting that Spanish pre-service primary school teachers were more positive towards the application of GMO than Swedish pre-service primary school teachers. These findings are in line with previous research that has consistently shown that European, and particularly Nordic, citizens' rejection of GM food is strong and persistent (Bredahl, 1999; Magnusson \& Hursti, 2002). However, it is noteworthy that no significant differences were found between the remaining attitude factors; any other differences were relatively small, and we conclude that there are more similarities than differences in Swedish and Spanish pre-service primary school teachers' attitudes towards biotechnology. The differences detected in earlier studies, such as European Commission (2010) and Gaskell et al. (2006), between northern and southern European countries 
are not prominent in our study. It might be that teachers in different European countries have more similar attitudes than the population at large, or that the attitudes have grown more similar in Europe over the last decade. This is an important hypothesis to pursue in future research.

\section{Limitations of the Study-and Future Research}

This study used a validated instrument, with the potential to provide generalizable findings. However, the use of nonrandomized samples is a limitation of the research design, as is the relatively small sample size. We cannot claim that the results are valid for all Swedish pre-service primary school teachers, but the results do provide an indication. Swedish teacher training is regulated by national authorities and therefore has a similar curriculum across its universities, and students attending primary teacher training have similar demographics, making the selected group of students a good representation.

Moreover, this study only covers two national contexts (Spain and Sweden) representing contrasting educational and cultural settings but providing very similar results. Therefore, in future research, it would be interesting to expand the scope of the study to investigate the generality of the results in other educational and cultural settings.

\section{Implications for Teaching and Teacher Training}

Teachers' knowledge and attitudes towards biotechnology are important because they will be teaching future generations within primary schools about biotechnology and its implications for society. This will be difficult to accomplish by teachers with gaps in their knowledge of basic genetics. Many personal, social, and cultural background factors can be hypothesized to influence student teachers' knowledge and attitudes towards biotechnology, and education is only one of these. However, we believe education is of paramount importance. It has been shown that younger pupils (12-year-olds versus 17-year-olds) have less favorable attitudes towards biotechnology (Dawson, 2007), indicating the importance of what they learn during their early years in primary education.

In the quest to develop biotechnological literacy, it is important for primary teachers to have a basic biotechnological knowledge, which is helped by a positive attitude. Teachers may not be inclined to like science and technology and its applications (van Alderen-Smeets et al., 2012), but a positive attitude is vital if they are to teach these topics. The results revealed by our "confidents" provide an attitudinal basis for developing the knowledge and teaching practices of biotechnology among primary teachers. We have shown that a developed curriculum of teacher training can inoculate a fertile ground, but it is a matter of policy and instruction to develop this further. In order to improve teacher knowledge, there is a need to create new educational material for them, or to train them about new advances in biotechnology, as shown successfully in previous studies (Casanoves et al., 2016; SoléLlussà et al., 2018).

Funding Open Access funding provided thanks to the CRUE-CSIC agreement with Springer Nature.

\section{Declarations}

Ethics Approval Not applicable.

Informed Consent Not applicable.

Conflict of Interest The authors declare no competing interests.

Open Access This article is licensed under a Creative Commons Attribution 4.0 International License, which permits use, sharing, adaptation, distribution and reproduction in any medium or format, as long as you give appropriate credit to the original author(s) and the source, provide a link to the Creative Commons licence, and indicate if changes were made. The images or other third party material in this article are included in the article's Creative Commons licence, unless indicated otherwise in a credit line to the material. If material is not included in the article's Creative Commons licence and your intended use is not permitted by statutory regulation or exceeds the permitted use, you will need to obtain permission directly from the copyright holder. To view a copy of this licence, visit http://creativecommons.org/licenses/by/4.0/.

\section{References}

Almomani, B. A., Al-Keilani, M. S., \& Al-Sawalha, N. A. (2020). Knowledge and views about genetics: A public-based crosssectional study. European Journal of Human Genetics, 28(4), 417-423.

Bahri, N. M., Suryawati, E., \& Osman, K. (2014). Students' biotechnology literacy: The pillars of STEM education in Malaysia. Eurasia Journal of Mathematics, Science and Technology Education, 10(3), 195-207.

Barnett, J., Cooper, H., \& Senior, V. (2007). Belief in public efficacy, trust, and attitudes toward modern genetic science. Risk Analysis, 27(4), 921-933. https://doi.org/10.1111/j.1539-6924.2007. 00932.x .PMID: 17958501.

Bredahl, L. (1999). Consumers cognitions with regard to genetically modified foods. Results of a qualitative study in four countries. Appetite, 33(3), 343-360. https://doi.org/10.1006/appe.1999. 0267

Bromme, R., \& Goldman, S. R. (2014). The public's bounded understanding of science. Educational Psychologist, 49(2), 59-69. https://doi.org/10.1080/00461520.2014.921572

Brosig, S., \& Bavorova, M. (2019). Association of attitudes towards genetically modified food among young adults and their referent persons. PLoS One, 14(2), e0211879.

Bruce, P. (2015). Introductory statistics and analytics: A resampling perspective. John Wiley \& Sons.

Buehl, M. M., \& Beck, J. S. (2015). The relationship between teachers' beliefs and teachers' practices. In H. Fives \& M. G. Gill 
(Eds.), International Handbook of research on teachers' beliefs (pp. 66-84). Routledge.

Bybee, R., McCrae, B., \& Laurie, R. (2009). PISA 2006: An assessment of scientific literacy. Journal of Research in Science Teaching, 46(8), 865-883.

Carver, R. B., Castéra, J., Gericke, N., Evangelista, N. A. M., \& El-Hani, C. N. (2017). Young adults' belief in genetic determinism, and knowledge and attitudes towards modern genetics and genomics: The PUGGS questionnaire. PLoS One, 12, e 0169808. https://doi.org/10.1371/journal.pone.0169808

Casanoves, M., González, Á., Salvadó, Z., Haro, J., \& Novo, M. (2015). Knowledge and attitudes towards biotechnology of elementary education preservice teachers: the first Spanish experience. International Journal of Science Education, 37(17), 2923-2941. https://doi.org/10.1080/00219266.2015.1058843

Casanoves, M., Salvadó, Z., González, A., Valls, C., \& Novo, M. (2016). Learning genetics through a scientific inquiry game. Journal of Biological Education, 51(2), 99-106. https://doi.org/ 10.1080/00219266.2016.1177569

Cebesoy, Ü. B., \& Öztekin, C. (2017). Genetics literacy: Insights from science teachers' knowledge, attitude, and teaching perceptions. International Journal of Science and Mathematics Education, 1-22.

Chabalengula, V. M., Mumba, F., \& Chitiyo, J. (2011). American elementary education pre-service teachers' attitudes towards biotechnology processes. International Journal of Environmental \& Science Education, 6(4), 341-357.

Condit, C. M. (2010). Public attitudes and beliefs about genetics. Annual Review of Genomics and Human Genetics., 11(1), 339-359.

Costa-Font, J., \& Mossialos, E. (2006). The public as a limit to technology transfer: The influence of knowledge and beliefs in attitudes towards biotechnology in the UK. The Journal of Technology Transfer, 31(6), 629-645.

Darçin, E. S. (2011). Turkish pre-service science teachers' knowledge and attitude towards application areas of biotechnology. Scientific Research and Essays, 6(5), 1013-1019. https://doi. org/10.5897/SRE10.552

Darçin, E. S., \& Güven, T. (2008). Development of an attitude measure oriented to biotechnology for the pre-service science teachers. Journal of Turkish Science Education, 5(3), 72-81.

Dawson, V. (2007). An exploration of high school (12-17 year old) students' understandings of, and attitudes towards biotechnology processes. Research in Science Education, 37(1), 59-73. https://doi.org/10.1007/s11165-006-9016-7

Delamarter, J. (2015). Avoiding practice shock: Using teacher movies to realign pre-service teachers' expectations of teaching. Australian Journal of Teacher Education, 40(2), n2.

Doudna, J. A., \& Charpentier, E. (2014). The new frontier of genome engineering with CRISPRCas9. Science, 346, 1258096.

Education, T. S. N. A. F. (2011). Curriculum for the compulsory school, preschool class and the leisure-time centre 2011. Retrieved from http://www.skolverket.se/2.3894/in_english/publications

Erdoğan, M., Özel, M., Bouiaoude, S., Usak, M., \& Prokop, P. (2012). Assessment of preservice teachers' knowledge and attitudes regarding biotechnology: A cross-cultural comparison. Journal of Baltic Science Education, 11(1).

European Commission. (2010). Special eurobarometer 341. Biotechnology. Brussels (Belgium): Directorate general research, EU. Retrieved from http://ec.europa.eu/public_opinion/archives/ebs/ ebs_341_en.pdf

García-Carmona, A., \& Cruz-Guzmán, M. (2016). ¿Con qué vivencias, potencialidades y predisposiciones inician los futuros docentes de Educación Primaria su formación en la enseñanza de la ciencia? [What experiences, potentials and predispositions initiate future teachers of primary education training in teaching science?].
Revista Eureka Sobre Enseñanza y Divulgación De Las Ciencias, 13(2), 440-458.

Gaskell, G., Allansdottir, A., Allum, N., Corchero, C., Fischler, C., Hampel, J., \& Schreiner, C. (2006). Europeans and biotechnology in 2005: Patterns and trends: Final report on Eurobarometer 64.3. http://ec.europa.eu/research/press/2006/pdf/pr1906_eb_64_3_ final_report-may2006_en.pdf

Gaskell, G., Stares, S., Allansdottir, A., Allum, N., Castro, P., Esmer, Y., \& Mejlgaard, N. (2010). Europeans and biotechnology in 2010. Winds of change? Brussels: European Commission.

Gericke, N., \& Smith, M. U. (2014). Twenty-first century genetics and genomics: Contributions of HPS - Informed research and pedagogy. In M. R. Matthews (Ed.), International Handbook of Research in History, Philosophy and Science Teaching (Vol. I, pp. 423-467). Springer.

González, A., Casanoves, M., Salvado, Z., Barnett, J., \& Novo, M. T. (2013). Biotechnology Literacy: Much More than a Gene Story. International Journal of Science in Society, 4(2).

Haney, J. J., Lumpe, A. T., Czerniak, C. M., \& Egan, V. (2002). From beliefs to actions: The beliefs and actions of teachers implementing change. Journal of Science Teacher Education, 13, 171-187. https://doi.org/10.1023/A:1016565016116

Jiménez-Salas, Z., Campos-Góngora, E., González-Martínez, B. E., Tijerina-Sáenz, A., Escamilla-Méndez, A. D., \& Ramírez-López, E. (2017). Basic-education Mexican teachers' knowledge of biotechnology and attitudes about the consumption of genetically modified foods. Biochemistry and Molecular Biology Education, 45(5), 396-402. https://doi.org/10.1002/bmb.21058

Kidman, G. (2009). Attitudes and interests towards biotechnology: The mismatch between students and teachers. Eurasian Journal of Mathematics, Science and Technology Education, 5(2), 135-143. Retrieved from http://eprints.qut.edu.au/28904/1/ 28904.pdf

Klop, T., \& Severiens, S. (2007). An exploration of attitudes towards modern biotechnology: A study among Dutch secondary school students. International Journal of Science Education, 29(5), 663679. https://doi.org/10.1080/09500690600951556

Klop, T. (2008). Attitudes of secondary school students towards modern biotechnology. (Unpublished doctoral dissertation). Erasmus University, Rotterdam (The Netherlands).

Lamanauskas, V., \& Makarskaite-Petkeviciene, R. (2008). Lithuanian university student's knowledge of biotechnology and their attitudes of the taught subject. Eurasian Journal of Mathematics, Science and Technology Education, 4(3), 269-277. Retrieved from http://www.ejmste.org/v4n3/EURASIA_v4n3_Lamanauskas.pdf

Laugksch, R. C. (2000). Scientific literacy: A conceptual overview. Science Education, 84(1), 71-94.

Lee, J. S., \& Ginsburg, H. P. (2007). Preschool teachers' beliefs about appropriate early literacy and mathematics education for low and middle socioeconomic status children. Early Education \& Development, 18, 111-143. https://doi.org/10.1080/10409280701274758

Magnusson, M. K., \& Hursti, U. K. (2002). Consumer attitudes towards genetically modified foods. Appetite, 39(1), 9-24. https://doi.org/ 10.1006/appe.2002.0486

Nunnally, J. C. (1978). Psychometric theory (2nd ed.). McGraw-Hill.

Orhan, T., \& Sahin, N. (2018). The impact of innovative teaching approaches on biotechnology knowledge and laboratory experiences of science teachers. Education Sciences, 8(4), 213. https:// doi.org/10.3390/educsci8040213

Prokop, P., Leskova, A., Kubiatko, M., \& Diran, C. (2007). Slovakian students' knowledge of and attitudes toward biotechnology. International Journal of Science Education, 29(7), 895-907. https:// doi.org/10.1080/09500690600969830

Real Decreto. (1105/2014). de 26 de diciembre, por el que se establece el currículo básico de la Educación Secundaria Obligatoria y del Bachillerato. Boletín Oficial del Estado, 3, de 3 de enero de 2015, 
169 a 546. Retrieved from https://www.boe.es/boe/dias/2015/01/ 03/pdfs/BOE-A-2015-37.pdf

Roberts, D. A. (2007). Scientific literacy/science literacy. In S. K. Abell \& N. G. Lederman (Eds.), Handbook of research on science education (pp. 729-780). Lawrence Erlbaum Associates.

Salvadó, Z., Casanoves, M., \& Novo, M. (2013). Building bridges between biotech and society through STSE education. The Journal of Deliberative Mechanisms in Science, 2(1).

Solé-Llussà, A., Casanoves, M., Salvadó, Z., Garcia-Vallvé, S., Valls, C., \& Novo, MT. (2018). Annapurna Expedition Game: applying molecular biology tools to learn genetics. Journal of Biological Education, 53(5), 516-523. https://doi.org/10.1080/00219266. 2018.1501409

Solli, A., Bach, F., \& Åkerman, B. (2014). Learning to argue as a biotechnologist: Disprivileging opposition to genetically modified food. Cultural Studies of Science Education, 9(1), 1-23.

Sorgo, A., \& Ambrozic-Dolinsek, J. (2009). The relationship among knowledge of, attitudes toward and acceptance of genetically modified organisms (GMOs) among Slovenian teachers. Electronic Journal of Biotechnology, 12(3), 1-13.

Šorgo, A., Ambrožič-Dolinšek, J., Ųsak, M., \& Özel, M. (2011). Knowledge about and acceptance of genetically modified organisms among pre-service teachers: A comparative study of Turkey and Slovenia. Electronic Journal of Biotechnology, 14(4). Retrieved 11 Feb 2021 from http://www.ejbiotechnology.info/ index.php/ejbiotechnology/article/view/v14n4-5/1330

Straathof, A. J., Wahl, S. A., Benjamin, K. R., Takors, R., Wierckx, N., \& Noorman, H. J. (2019). Grand research challenges for sustainable industrial biotechnology. Trends in Biotechnology, 37(10), 1042-1050.

Usak, M., Erdogan, M., Prokop, P., \& Ozel, M. (2009). High school and university students' knowledge and attitudes regarding biotechnology. Biochemistry and Molecular Biology Education, 37(2), 123-130. https://doi.org/10.1002/bmb.20267

van Alderen-Smeets, S. I., Warma van der Molen, J. H., \& Asma, L. J. F. (2012). Primary teachers' attitudes toward science: A new theoretical framework. Science Education, 96(1), 158-182.

Zoller, U. (2012). Science education for global sustainability: What is necessary for teaching, learning, and assessment strategies? Journal of Chemical Education, 89, 297-300. https://doi.org/10. 1021/ed300047v

Publisher's Note Springer Nature remains neutral with regard to jurisdictional claims in published maps and institutional affiliations. 